\title{
Molecular Characterization of the Vairimorpha (Nosema) ceranae Infection from Bombus terrestris (Linnaeus, 1758) (Hymenoptera: Apidae) in Turkey
}

\author{
Onur TOSUN ${ }^{1 *} \quad$ Çağrı BEKIRCAN ${ }^{2}$ \\ ${ }^{1}$ Karadeniz Technical University, Maçka Vocational School, Department of Veterinary \\ Medicine, Trabzon, TURKEY \\ ${ }^{2}$ Selçuk University, Sarayönü Vocational School, Department of Veterinary Medicine, Konya, \\ TURKEY \\ e-mails: ${ }^{1 *}$ onrtsn61@hotmail.com, ${ }^{2}$ cagribekircan@hotmail.com \\ ORCID IDs: ${ }^{1 * 0000-0002-6763-5671, ~}{ }^{20000-0002-5968-7359 ~}$
}

\begin{abstract}
The current study aimed to determine the natural Microsporidium pathogen of the Bombus terrestris L. (Hymenoptera: Apidae) in Turkey (Mersin, Antalya, Muğla, İzmir, Aydın). During 2019 and 2020, the commercial and wild populations of $B$. terrestris were investigated in this survey. In the studies, natural microsporidiosis was detected in commercial $B$. terrestris populations. Fresh oval spores were measured as $4.91 \pm 0.48(6.12-3.73) \mu \mathrm{m}$ in length and $2.54 \pm 0.31(3.27$ - 1.88) $\mu \mathrm{m}$ in width $(n=60)$. Both SSU rRNA and RPB1 gene sequences of the current microsporidium were top hits with the Vairimorpha (Nosema) ceranae isolates. While the SSU rRNA gene sequence matched with the Vairimorpha ceranae clone NCS44 (LC510228) isolated from the Apis cerana japonica at $99.24 \%$ identity (100\% coverage), the RPB1 gene sequence was matched with the Vairimorpha ceranae isolate 1994 (KJ473287) at 99.02\% identity ( $100 \%$ coverage). Based on the light microscopy and molecular phylogeny the current microsporidium was a new isolate of the $V$. ceranae and named here in as Vairimorpha ceranae $\mathrm{Tr}-07$.
\end{abstract}

Key words: Bombus terrestris, microsporidiosis, RPB1, SSU rRNA, Vairimorpha ceranae.

Tosun, O. \& Bekircan, Ç. (2021). Molecular characterization of the Vairimorpha (Nosema) ceranae infection from Bombus terrestris (Linnaeus, 1758) (Hymenoptera: Apidae) in Turkey. Journal of the Entomological Research Society, 32(3), 305-319. 


\section{INTRODUCTION}

Bees are infected by lots of pathogens and parasites that cause abnormalities in their metabolism, immune system, behavior and perception (Antúnez et al, 2009; Gómez-Moracho, Heeb, \& Lihoreau, 2017; Li, Chen \& Cook, 2018). As a result of these infections, bee individuals and colonies lose their fitness. Undoubtedly, Vairimorpha (Nosema) ceranae is the most common pathogen in bee species. The infection caused by $V$. ceranae, show different symptoms on their hosts at the physiological levels as changing gene expression in the brain, inhibiting the apoptosis of epithelial cells and deregulating immune responses (Holt, Aronstein, \& Grozinger, 2013; Martín-Hernández et al, 2017; 2018) and behavioral levels as starting foraging earlier in life, exhibiting more frequent but shorter foraging flights, reducing homing abilities and lowering olfactory learning performances (Wolf et al, 2014; Dosselli, Grassl, Carson, Simmons, \& Baer, 2016; Perry, Søvik, Myerscough, \& Barron, 2016; Gage et al, 2018).

In recent years, $V$. ceranae has been frequently identified in wild bee species, especially bumblebees (Bombus spp.) (Plischuk et al, 2009; Li et al, 2012; Graystock, Yates, Darvill, Goulson, \& Hughes, 2013). The V. ceranae infection in bumblebees causes reduced foraging performance of all colonies and damages their cognitive skills (Piiroinen \& Goulson, 2016).

Numerical declines and local extinctions in bumblebee species have been reported in recent years. Studies have shown that four species have begun to disappear in Europe, and two species have been completely extinct in the British Isles (Goulson, Lye, \& Darvill, 2008). Also, significant decreases were found in the populations of different bumblebees in North America, England and Ireland (Fitzpatrick et al, 2007; Grixti, Wong, Cameron, \& Favret, 2009; Williams \& Osborne, 2009). it has been stated that one of the important causes of these losses is parasites and pathogens (Cox-Foster et al, 2007; Cameron et al, 2011).

Bumblebees, which are important in pollination was determined about a hundred years ago, have been mass-produced for the past 25 years and are widely used as pollinators in greenhouse cultivation (Güler, Aytekin, \& Dikmen, 2011; Argun Karslı \& Gürel, 2015). More than one million bumblebees are commercially produced annually in the world, and more than $90 \%$ of this is Bombus terrestris L. (Hymenoptera: Apidae) (Velthius \& Doorn, 2006). Parasites and pathogens in bumblebees must be accurately and rapidly identified to prevent damage to native species and to safely carry out commercial bumblebee colony breeding. For this aim, the present study tries to determine the natural pathogen and parasites of the Bombus terrestris L. in Turkey.

\section{MATERIALS AND METHODS}

\section{Specimen collection and Light microscopical observation}

In this study, commercially produced and wild-type members of the $B$. terrestris were collected and were examined for parasites and pathogens. While the commercially produced members were collected from greenhouses in five different provinces 
Molecular Characterization of the Vairimorpha (Nosema) ceranae

(Mersin, Antalya, Muğla, İzmir, Aydın), the wild type adult members of the $B$. terrestris were collected from the north-east part of Turkey (Artvin, Trabzon, Rize, Giresun, Ordu) in 2019-2020. During the field study, due to the low population densities of the wild type, the sample numbers were less than expected. Samples were caught with sweep nets and live samples were transported immediately to the laboratory for further examinations. On the other hand, the samples which were collected commercially produced members from greenhouses lands or hives, had been found dead when collected. Members of $B$. terrestris morphologically identified according to Mauss (1994) and for wet mount preparation samples were dissected with Ringer's solution and examined under the light microscope (Tosun, 2020; Yıldırım \& Bekircan, 2020). Infection positive slides were photographed using Zeiss AXIO microscope equipped with an Axicam ERc5s digital camera. The necessary measurements and analysis were made using ZEN 2.3 Blue Edition imaging software. While some infection-positive remaining tissues were preserved in 95\% ethanol for molecular studies, others were preserved in $2.5 \%$ glutaraldehyde in PBS for transmission electron microscopy.

\section{DNA extraction, Amplification and Molecular analysis}

Ethanol-fixed infected tissues were washed with distilled water 3 times (15 min) to remove ethanol. The genomic DNA was extracted using the QIAGEN DNA Isolation Kit, No: 69504 according to the manufacturer's instructions. To amplify the SSU rRNA gene, the QIAGEN Multiplex PCR Kit (No. 206143) and 18F/1537R primer set was used (Baki \& Bekircan, 2018). Amplification processes were performed according to the kit's protocol in a $50 \mu \mathrm{l}$ reaction system. Amplification conditions were as follows: an initial denaturation step at $95^{\circ} \mathrm{C}$ for $15 \mathrm{~min}$, followed by 40 cycles of denaturation at $94{ }^{\circ} \mathrm{C}$ for $1 \mathrm{~min}$, annealing at $60^{\circ} \mathrm{C}$ for $90 \mathrm{~s}$, elongation at $72{ }^{\circ} \mathrm{C}$ for $2 \mathrm{~min}$ and a final extension at $72^{\circ} \mathrm{C}$ for $10 \mathrm{~min}$. Also, in the present study, the largest subunit of RNA polymerase II (RPB1) gene alignments were amplified as in the SSU rRNA gene. To amplify, the QIAGEN Multiplex PCR Kit (No. 206143) and primer set were used (Tosun, 2020; Yıldırım, 2021). The base sequences of the SSU rRNA and RPB1 gene were determined in the Macrogen Inc. Company, The Netherlands.

The sequences fragments were assembled using BioEdit and obtained consensus sequences (Hall, 1999)"mendeley":: "formattedCitation":"(Hall, 1999. Sequences with high similarity were determined according to the BLAST search and those of our interest were retrieved from the NCBI GenBank database and the literature (Table 1). The new combinations were used as re-assigned in 2020 by Tokarev et al, in the phylogenetic analysis (Tokarev et al, 2020). In the analysis, all sequences were aligned with CLUSTAL_W. Pairwise genetic distances were determined using the Kimura-2 parameter. Phylogenetic analyses were conducted using the maximum likelihood (ML) method in MEGA 10. Bootstrap confidence values were calculated with 1000 repetitions and the optimal evolutionary model was determined as GTR +I + G. 
TOSUN, O. \& BEKIRCAN, Ç.

Table 1. Small subunit (SSU) ribosomal RNA and RNA polymerase II largest subunit (RPB1) gene sequences used for phylogenetic analyses.

\begin{tabular}{|c|c|c|c|c|c|}
\hline & Accession No & Organism name & Host & Order & Family \\
\hline \multirow{22}{*}{ 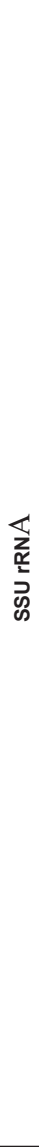 } & MW396669 & Vairimorpha (Nosema) cerenaeTr-07 & Bombus terrestris & Hymenoptera & Apidae \\
\hline & LC510251 & Vairimorpha ceranae (Japan) & Apis cerana & Hymenoptera & Apidae \\
\hline & LC510228 & Vairimorpha ceranae (Japan) & Apis cerana & Hymenoptera & Apidae \\
\hline & DQ673615 & Vairimorpha ceranae (Switzerland) & Apis mellifera & Hymenoptera & Apidae \\
\hline & DQ329034 & Vairimorpha ceranae (Spain) & Apis mellifera & Hymenoptera & Apidae \\
\hline & KU937104 & Vairimorpha ceranae (India) & Apis mellifera & Hymenoptera & Apidae \\
\hline & KC680654 & Vairimorpha ceranae (Thailand) & Apis mellifera & Hymenoptera & Apidae \\
\hline & KC680650 & Vairimorpha ceranae (Thailand) & Bombus sp. & Hymenoptera & Apidae \\
\hline & JN872261 & Vairimorpha ceranae (China) & Bombus sp. & Hymenoptera & Apidae \\
\hline & DQ235446 & Vairimorpha apis (Spain) & Apis mellifera & Hymenoptera & Apidae \\
\hline & FJ789796 & Vairimorpha apis (Australia) & Apis mellifera & Hymenoptera & Apidae \\
\hline & U11047 & Vairimorpha vespula & Vespula vulgaris & Hymenoptera & Vespidae \\
\hline & Y00266 & Vairimorpha necatrix & $\begin{array}{l}\text { Pseudaletia } \\
\text { unipuncta }\end{array}$ & Lepidoptera & Noctuidae \\
\hline & HМ370543 & Nosema bombi (Russia) & Bombus lucorum & Hymenoptera & Apidae \\
\hline & KF002566 & Nosema bombi (Mexico) & Bombus ephippiatus & Hymenoptera & Apidae \\
\hline & JN872231 & Nosema bombi (China) & Bombus sp. & Hymenoptera & Apidae \\
\hline & MF776532 & Nosema bombi (Thailand) & Bombus sp. & Hymenoptera & Apidae \\
\hline & AY741105 & Nosema bombi (Ireland) & Bombus pascuorum & Hymenoptera & Apidae \\
\hline & KF916504 & Nosema bombi (Turkey) & Bombus sp. & Hymenoptera & Apidae \\
\hline & D85503 & Nosema bombycis & Bombyx mori & Lepidoptera & Bombycidae \\
\hline & KT020736 & Nosema fumiferanae & Epiphyas postvittana & Lepidoptera & Tortricidae \\
\hline & L39109 & Endoreticulatus schubergi & $\begin{array}{l}\text { Cholistoneura } \\
\text { fumiferana }\end{array}$ & Lepidoptera & Tortricidae \\
\hline \multirow{9}{*}{$\frac{\bar{m}}{\frac{1}{\alpha}}$} & MW415412 & Vairimorpha (Nosema) cerenaeTr-07 & Bombus terrestris & Hymenoptera & Apidae \\
\hline & KJ473287 & Vairimorpha ceranae (Chile) & Apis mellifera & Hymenoptera & Apidae \\
\hline & KM001627 & Vairimorpha ceranae (China) & Apis ceranae & Hymenoptera & Apidae \\
\hline & DQ996230 & Vairimorpha apis & Apis mellifera & Hymenoptera & Apidae \\
\hline & AF060234 & Vairimorpha necatrix & $\begin{array}{l}\text { Pseudaletia } \\
\text { unipuncta }\end{array}$ & Lepidoptera & Noctuidae \\
\hline & DQ996236 & Vairimorpha necatrix & $\begin{array}{l}\text { Pseudaletia } \\
\text { unipuncta }\end{array}$ & Lepidoptera & Noctuidae \\
\hline & JX213749 & Vairimorpha lymantriae & Lymantria dispar & Lepidoptera & Lymantria \\
\hline & JX239748 & Vairimorpha disparis & Lymantria dispar & Lepidoptera & Erebidae \\
\hline & MT461295 & Nosema fumiferanae TY61 & $\begin{array}{l}\text { Apomyelois } \\
\text { (Ectomyelois) } \\
\text { ceratoniae }\end{array}$ & Lepidoptera & Pyralidae \\
\hline
\end{tabular}


Molecular Characterization of the Vairimorpha (Nosema) ceranae

Table 1. Continued.

\begin{tabular}{|c|c|c|c|c|}
\hline Accession No & Organism name & Host & Order & Family \\
\hline HQ457435 & Nosema fumiferanae & $\begin{array}{l}\text { Choristoneura } \\
\text { fumiferana }\end{array}$ & Lepidoptera & Tortricidae \\
\hline HQ457436 & Nosema sp. & $\begin{array}{l}\text { Choristoneura } \\
\text { occidentalis }\end{array}$ & Lepidoptera & Tortricidae \\
\hline AJ278948 & Nosema tyriae & Tyria jacobaeae & Lepidoptera & Arctiidae \\
\hline DQ996231 & Nosema bombycis & Bombyx mori & Lepidoptera & Bombycidae \\
\hline DQ996234 & Nosema trichoplusiae & Trichoplusia ni & Lepidoptera & Noctuidae \\
\hline HQ457438 & Nosema disstriae & Malacasoma disstria & Lepidoptera & Lasiocampidae \\
\hline DQ996232 & Nosema empoascae & Empoasca fabae & Homoptera & Cicadellidae \\
\hline DQ996233 & Nosema granulosis & Gammarus duebeni & Amphipoda & Gammaridae \\
\hline XM 014708712 & Ordospora colligata & Daphnia magna & Cladocera & Daphniidae \\
\hline
\end{tabular}

\section{RESULTS}

\section{Light microscopy}

In the present study, the commercially produced members of the $B$. terrestris were collected from greenhouses where tomato production was carried out in five different provinces: Mersin, Antalya, Muğla, İzmir and Aydın. In this survey, 547 samples were collected from greenhouses and examined during 2019-2020. As a result of the examinations, 51 samples were infected by the microsporidian pathogen (infection rate: $9.32 \%)$. Determined fresh oval spores were measured as $4.91 \pm 0.48(6.12$ - 3.73) $\mu \mathrm{m}$ in length and $2.54 \pm 0.31(3.27-1.88) \mu \mathrm{m}$ in width $(n=60)$. Infected members gut systems fully filled with the oval mature spores (Fig. 1). In addition, during this study 171 wild members were collected from the provinces (Artvin, Rize, Trabzon, Giresun and Ordu) where those of determined before. As a result of the examinations, no microsporidiosis was found in the smears prepared from wild members (Table 2). Therefore, this group was not included in subsequent statistical analysis.

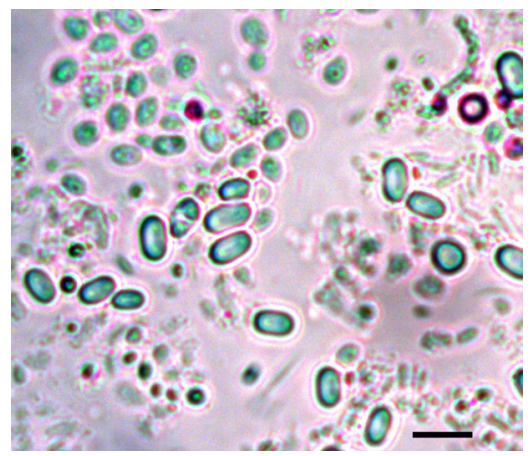

Fig. 1. The light micrograph of the $V$. ceranae Tr-07 fresh oval spores, bar: $5 \mu \mathrm{m}$. 
The infection prevalence was calculated based on the rate of bumblebees determined to be microsporidiosis positive with the microscopic examination in this study. After the analysis, infection prevalence based on provinces was determined as $14.28 \%$ in Mersin, $15.74 \%$ in Antalya, $14.28 \%$ in Muğla, respectively. No infection was detected in İzmir and Aydın. When comparing the infection rates on a year and month basis it was seen that the infection rate was $9.81 \%$ in 2019 and $8.86 \%$ in 2020 where in months, these rates were a range from $9.65 \%$ in May, $10.16 \%$ in June and $8.15 \%$ in July, respectively (Table 2 ).

\section{Molecular phylogeny}

The molecular phylogeny of the current microsporidium which isolated from infected B. terrestris tissues was based on the partial SSU rRNA and RPB1 gene. An 1177 nucleotide section of the SSU rRNA and 674 nucleotides of the RPB1 were obtained with $35.9 \%$ and $32.5 \%$ GC content after the sequencing. And these sequences of the current microsporidium were deposited in GenBank with MW396669 and MW415412 accession codes. Each sequence was subjected to BLAST analysis that matched only microsporidian records. Both SSU rRNA and RPB1 gene sequences of the current microsporidium were top hits with the $V$. ceranae isolates. While the SSU rRNA gene sequence matched with the Vairimorpha ceranae clone NCS44 (LC510228) isolated from the Apis cerana japonica at $99.24 \%$ identity (100\% coverage), the RPB1 gene sequence was matched with the Vairimorpha ceranae isolate 1994 (KJ473287) at $99.02 \%$ identity ( $100 \%$ coverage).

The pairwise distance analysis that carried for the SSU rRNA gene sequence, was conducted with 22 microsporidian sequences. Pairwise phylogenetic distances between the current microsporidium and other species ranged from 0.010 to 0.505 . The distance between the current microsporidium and the type species of the genus, Vairimorpha necatrix (Pilley, 1976) was determined as 0.068 (Table 3). Also, it was differentiating from the Nosema bombycis (Nägeli, 1857), the type species of Nosema genus, with 0.243 difference.

For RPB1 gene sequence, 18 microsporidian sequences were used in the pairwise phylogenetic distance analysis. And the distances were ranged from 0.010 to 0.388 . In the analysis made on the RPB1 gene, they gave results that support the results of the analysis made with the SSU rRNA gene. And, the current microsporidium was more closely related to the Vairimorpha species (Table 3).

In conclusion, based on the morphological and molecular information, the current microsporidium isolated from $B$. terrestris was a new isolate of Vairimorpha ceranae. 
Molecular Characterization of the Vairimorpha (Nosema) ceranae

Table 2. Vairimorpha (Nosema) cerenae infection in B. terrestris from the different sampling localities and months.

\begin{tabular}{|c|c|c|c|c|c|c|c|c|}
\hline & Sample type & Province & Months & $\begin{array}{l}\text { Dissected } \\
\text { samples }\end{array}$ & Total & $\begin{array}{l}\text { Infected } \\
\text { samples }\end{array}$ & $\begin{array}{c}\text { Infection rate } \\
(\%)\end{array}$ & $\begin{array}{l}\text { Total infection } \\
\text { rate (\%) }\end{array}$ \\
\hline \multirow{30}{*}{ 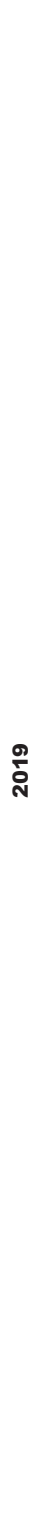 } & \multirow{15}{*}{ Commercial } & \multirow{3}{*}{ Mersin } & May & 15 & \multirow{3}{*}{48} & 4 & 26.67 & \multirow{3}{*}{14.58} \\
\hline & & & June & 20 & & 3 & 15 & \\
\hline & & & July & 13 & & - & - & \\
\hline & & \multirow{3}{*}{ Antalya } & May & 20 & \multirow{3}{*}{62} & 3 & 15 & \multirow{3}{*}{19.35} \\
\hline & & & June & 22 & & 5 & 22.73 & \\
\hline & & & July & 20 & & 4 & 20 & \\
\hline & & \multirow{3}{*}{ Muğla } & May & 15 & \multirow{3}{*}{52} & 2 & 13.33 & \multirow{3}{*}{13.46} \\
\hline & & & June & 17 & & 3 & 17.64 & \\
\hline & & & July & 20 & & 2 & 10 & \\
\hline & & \multirow{3}{*}{ İzmir } & May & 15 & \multirow{3}{*}{55} & - & - & \multirow{3}{*}{ - } \\
\hline & & & June & 20 & & - & - & \\
\hline & & & July & 20 & & - & - & \\
\hline & & \multirow{3}{*}{ Aydın } & May & 17 & \multirow{3}{*}{48} & - & - & \multirow{3}{*}{ - } \\
\hline & & & June & 13 & & - & - & \\
\hline & & & July & 18 & & - & - & \\
\hline & \multirow{15}{*}{ Wild } & \multirow{3}{*}{ Artvin } & April & 9 & \multirow{3}{*}{18} & - & - & \multirow{3}{*}{ - } \\
\hline & & & May & 6 & & - & - & \\
\hline & & & June & 3 & & - & - & \\
\hline & & \multirow{3}{*}{ Rize } & April & 6 & \multirow{3}{*}{15} & - & - & \multirow{3}{*}{ - } \\
\hline & & & May & 4 & & - & - & \\
\hline & & & June & 5 & & - & - & \\
\hline & & \multirow{3}{*}{ Trabzon } & April & 10 & \multirow{3}{*}{21} & - & - & \multirow{3}{*}{ - } \\
\hline & & & May & 7 & & - & - & \\
\hline & & & June & 4 & & - & - & \\
\hline & & \multirow{3}{*}{ Giresun } & April & 5 & \multirow{3}{*}{14} & - & - & \\
\hline & & & May & 3 & & - & - & - \\
\hline & & & June & 6 & & - & - & \\
\hline & & & April & 3 & & - & - & \\
\hline & & Ordu & May & 5 & 13 & - & - & - \\
\hline & & & June & 5 & & - & - & \\
\hline
\end{tabular}


TOSUN, O. \& BEKIRCAN, Ç.

Table 2. Continued.

\begin{tabular}{|c|c|c|c|c|c|c|c|c|}
\hline & $\begin{array}{c}\text { Sample } \\
\text { type }\end{array}$ & Province & Months & $\begin{array}{l}\text { Dissected } \\
\text { samples }\end{array}$ & Total & $\begin{array}{l}\text { Infected } \\
\text { samples }\end{array}$ & $\begin{array}{c}\text { Infection rate } \\
(\%)\end{array}$ & $\begin{array}{c}\text { Total } \\
\text { infection rate }(\%)\end{array}$ \\
\hline \multirow{30}{*}{ ণ্ণ } & \multirow{15}{*}{ Commercial } & \multirow{3}{*}{ Mersin } & May & 22 & \multirow{3}{*}{57} & 3 & 13.63 & \multirow{3}{*}{14.03} \\
\hline & & & June & 20 & & 2 & 10 & \\
\hline & & & July & 15 & & 3 & 20 & \\
\hline & & \multirow{3}{*}{ Antalya } & May & 18 & \multirow{3}{*}{65} & 3 & 16.66 & \multirow{3}{*}{12.30} \\
\hline & & & June & 22 & & 2 & 9.09 & \\
\hline & & & July & 25 & & 3 & 12 & \\
\hline & & \multirow{3}{*}{ Muğla } & May & 20 & \multirow{3}{*}{60} & 2 & 10 & \multirow{3}{*}{13.33} \\
\hline & & & June & 18 & & 2 & 11.11 & \\
\hline & & & July & 22 & & 4 & 18.18 & \\
\hline & & \multirow{3}{*}{ İzmir } & May & 22 & \multirow{3}{*}{55} & - & - & \multirow{3}{*}{-} \\
\hline & & & June & 18 & & - & - & \\
\hline & & & July & 15 & & - & - & \\
\hline & & \multirow{3}{*}{ Aydın } & May & 14 & \multirow{3}{*}{45} & - & - & \multirow{3}{*}{-} \\
\hline & & & June & 13 & & - & - & \\
\hline & & & July & 18 & & - & - & \\
\hline & \multirow{15}{*}{ Wild } & \multirow{3}{*}{ Artvin } & May & 4 & \multirow{3}{*}{13} & - & - & \multirow{3}{*}{-} \\
\hline & & & June & 6 & & - & - & \\
\hline & & & July & 3 & & - & - & \\
\hline & & \multirow{3}{*}{ Rize } & May & 9 & \multirow{3}{*}{19} & - & - & \multirow{3}{*}{-} \\
\hline & & & June & 5 & & - & - & \\
\hline & & & July & 5 & & - & - & \\
\hline & & \multirow{3}{*}{ Trabzon } & May & 11 & \multirow{3}{*}{25} & - & - & \multirow{3}{*}{-} \\
\hline & & & June & 6 & & - & - & \\
\hline & & & July & 8 & & - & - & \\
\hline & & \multirow{3}{*}{ Giresun } & May & 5 & \multirow{3}{*}{15} & - & - & \\
\hline & & & June & 6 & & - & - & - \\
\hline & & & July & 4 & & - & - & \\
\hline & & & May & 6 & & - & - & \\
\hline & & Ordu & June & 8 & 18 & - & - & - \\
\hline & & & July & 4 & & - & - & \\
\hline & & & GENE & L TOTAL & 718 & & & $7.10 \%$ \\
\hline
\end{tabular}


Molecular Characterization of the Vairimorpha (Nosema) ceranae

Table 3. Comparison of current microsporidium and other related microsporidia based on the small subunit ribosomal RNA gene (SSU rRNA) and the largest subunit of RNA polymerase II (RPB1) gene by query cover, by nucleotide identity, by Pairwise distance analysis, and GC\% content.

\begin{tabular}{|c|c|c|c|c|c|}
\hline \multirow{22}{*}{ 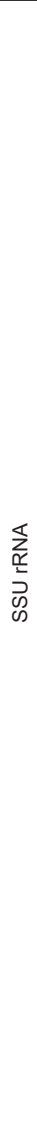 } & MW396669 & Vairimorpha (Nosema) cerenaeTr-07 & Query cover \% & Pairwise distances & $\begin{array}{c}\text { GC content } \\
(35.9 \%)\end{array}$ \\
\hline & LC510251 & Vairimorpha ceranae (Japan) & 99 & 0.01046 & 36.3 \\
\hline & LC510228 & Vairimorpha ceranae (Japan) & 99 & 0.01046 & 38.1 \\
\hline & DQ673615 & Vairimorpha ceranae (Switzerland) & 98 & 0.01752 & 38.8 \\
\hline & DQ329034 & Vairimorpha ceranae (Spain) & 98 & 0.01752 & 36.1 \\
\hline & KU937104 & Vairimorpha ceranae (India) & 99 & 0.01046 & 40 \\
\hline & KC680654 & Vairimorpha ceranae (Thailand) & 92 & 0.01046 & 36.1 \\
\hline & KC680650 & Vairimorpha ceranae (Thailand) & 92 & 0.01046 & 37.3 \\
\hline & JN872261 & Vairimorpha ceranae (China) & 42 & 0.01046 & 41.3 \\
\hline & DQ235446 & Vairimorpha apis (Spain) & 99 & 0.09585 & 38.7 \\
\hline & FJ789796 & Vairimorpha apis (Australia) & 92 & 0.09585 & 38.5 \\
\hline & U11047 & Vairimorpha vespula & 99 & 0.03184 & 36.8 \\
\hline & Y00266 & Vairimorpha necatrix & 99 & 0.06882 & 37.4 \\
\hline & HM370543 & Nosema bombi (Russia) & 58 & 0.06883 & 35.8 \\
\hline & KF002566 & Nosema bombi (Mexico) & 38 & 0.06883 & 35.8 \\
\hline & JN872231 & Nosema bombi (China) & 40 & 0.07266 & 35.7 \\
\hline & MF776532 & Nosema bombi (Thailand) & 22 & 0.07065 & 33.8 \\
\hline & AY741105 & Nosema bombi (Ireland) & 97 & 0.06550 & 35.9 \\
\hline & KF916504 & Nosema bombi (Turkey) & 25 & 0.07266 & 36.3 \\
\hline & D85503 & Nosema bombycis & 93 & 0.24367 & 34.1 \\
\hline & KT020736 & Nosema fumiferanae & 94 & 0.24862 & 32.3 \\
\hline & L39109 & Endoreticulatus schubergi & 71 & 0.50510 & 51 \\
\hline \multirow{6}{*}{$\begin{array}{l}\check{m} \\
\underline{\alpha}\end{array}$} & MW415412 & Vairimorpha(Nosema)cerenaeTr-07 & Query cover \% & Pairwise distances & $\begin{array}{c}\text { GC content } \\
(32.5 \%)\end{array}$ \\
\hline & KJ473287 & Vairimorpha ceranae & 100 & 0.01077 & 32.4 \\
\hline & KM001627 & Vairimorpha ceranae & 100 & 0.01319 & 32.2 \\
\hline & DQ996230 & Vairimorpha apis & 98 & 0.22293 & 31.2 \\
\hline & AF060234 & Vairimorpha necatrix & 98 & 0.23869 & 32.5 \\
\hline & DQ996236 & Vairimorpha necatrix & 98 & 0.23869 & 30.9 \\
\hline
\end{tabular}


TOSUN, O. \& BEKIRCAN, Ç.

Table 3. Continued.

\begin{tabular}{|c|c|c|c|c|c|}
\hline & MW396669 & Vairimorpha (Nosema) cerenaeTr-07 & Query cover \% & Pairwise distances & $\begin{array}{c}\text { GC content } \\
(35.9 \%)\end{array}$ \\
\hline \multirow{9}{*}{$\begin{array}{l}\overline{\underline{0}} \\
\frac{0}{\alpha}\end{array}$} & HQ457435 & Nosema fumiferanae & 94 & 0.27867 & 36.4 \\
\hline & HQ457436 & Nosema sp. & 94 & 0.26972 & 36.8 \\
\hline & AJ278948 & Nosema tyriae & 98 & 0.26806 & 36.7 \\
\hline & DQ996231 & Nosema bombycis & 98 & 0.26759 & 36.6 \\
\hline & DQ996234 & Nosema trichoplusiae & 98 & 0.27150 & 36.7 \\
\hline & HQ457438 & Nosema disstriae & 96 & 0.27711 & \\
\hline & DQ996232 & Nosema empoascae & 95 & 0.34913 & 43.6 \\
\hline & DQ996233 & Nosema granulosis & 94 & 0.29770 & 42.9 \\
\hline & XM 014708712 & Ordospora colligata & 89 & 0.38837 & 43.3 \\
\hline
\end{tabular}

“-“No significant similarity found.

\section{DISCUSSION}

This survey of pathogens of the $B$. terrestris from different provinces of Turkey showed that while the microsporidiosis originated from $V$. ceranae was commonly occur at commercial bumblebee populations in Turkey, no infection was found in wild populations. If it was necessary to make a self-criticism of the study here, it can be said that the reason for the no determination of any infection in wild populations was due to the low sample count. Because recent studies showed that the wild Bombus species were frequently infected with the microsporidian species like a $V$. ceranae (Li et al, 2012; Plischuk \& Lange, 2016; Sinpoo, Disayathanoowat, Williams, \& Chantawannakul, 2019).

The current microsporidium detected from commercial members of the $B$. terrestris was determined to be the first $V$. ceranae isolate of Turkey as a result of both microscopical and molecular examinations. The microsporidial taxonomy was constructed based on light microscopy and measurements (Kudo, 1924; Weiser, 1977; Sprague, Becnel, \& Hazard, 1992). In the examinations made in this context, it was determined that the current microsporidium spores had similar features to the data presented by numerous studies previously conducted for the definition and detection of V. ceranae (Fries, Feng, da Silva, Slemenda, \& Pieniazek, 1996; Chen et al, 2009). Especially in the last quarter, the microsporidial taxonomy has been constructed with the molecular phylogeny and species identifications are made on this basis (Baker, Vossbrinck, Maddox, \& Undeen, 1994; Baker, Vossbrinck, Didier, Maddox, \& Shadduck, 1995; Huang, Tsai, Lo, Soichi \& Wang 2004; Bekircan, 2020; Tokarev et al, 2020; Tosun, 2020) 1968 (Microsporidia: Nosematidae. Therefore, in this study partial sequences of SSU rRNA and RPB1 genes of the current microsporidium were analyzed. In the BLAST analysis conducted with partial sequences of the SSU rRNA and RPB1 genes, the current microsporidium showed high similarities with $V$. 
Molecular Characterization of the Vairimorpha (Nosema) ceranae

ceranae isolates (Table 3). According to SSU rRNA pairwise distance analysis, the current microsporidium was differentiating with only 0.010 from $V$. ceranae Thailand (KC680650) and China (JN872261) isolates, which were isolated from Bombus species (Sinpoo et al, 2019). The phylogenetic trees, which were constructed with SSU rRNA and RPB1 gene sequences, displayed two distinct clades: Nosema and Vairimorpha (Fig. 2). In both trees, the current microsporidium was grouping with the type species (V. necatrix) of the Vairimorpha genus and branched with the $V$. ceranae isolates. In the SSU rRNA tree, the current microsporidium settled the same node with the Switzerland (DQ673615) and Spain (DQ329034) isolates of the V. ceranae which were isolated from the Apis mellifera (Higes, García-Palencia, Martín-Hernández, \& Meana, 2007; Martín-Hernández et al, 2007) (Table 3). And the distances between the current microsporidium and these isolates were determined as the same $(0.017)$. Also, in the RPB1 tree, the current microsporidium settled the same node with the V. ceranae isolates (KJ473287 and KM001627) as in the SSU rRNA tree (Fig. 2).

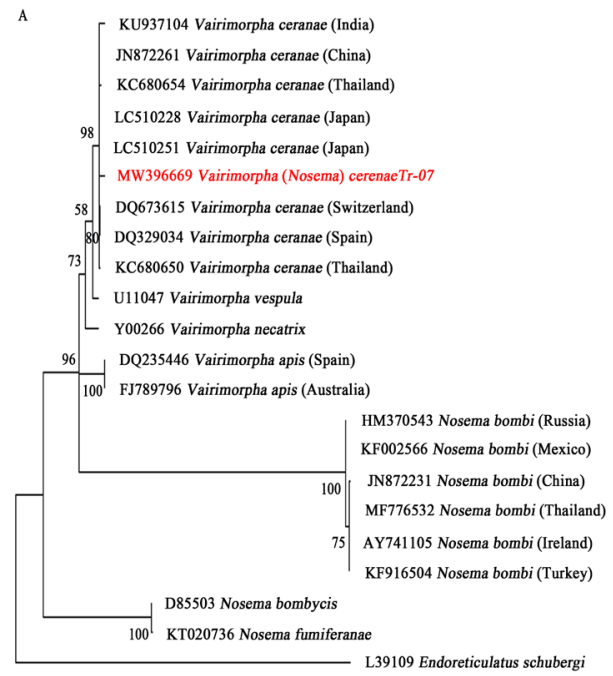

$\longmapsto$

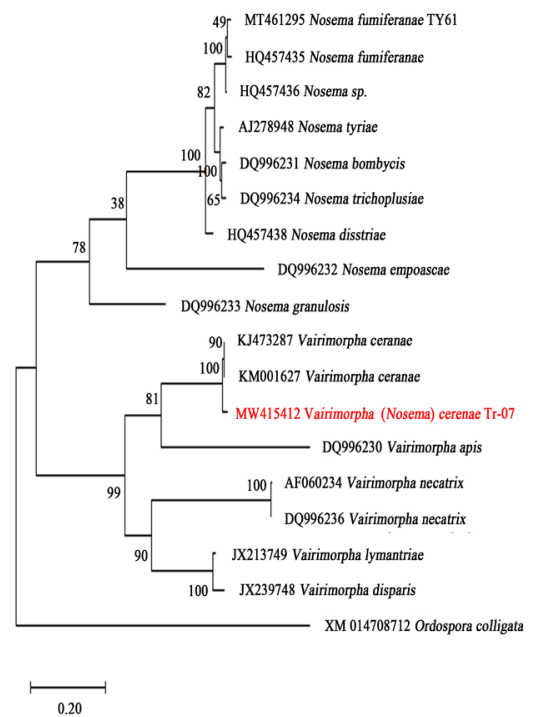

0.20

Fig. 2. Phylogenetic trees constructed by maximum likelihood (ML) revealed that the current microsporidium whose sequences were obtained in the present study was most closely related to the $V$. ceranae isolates. Endoreticulatus schubergi (L39109) and Ordospora colligata (XM014708712) were used as outgroups. The analysis was done on 1000 bootstrapped data sets. Bootstrap values were shown at each node. The scale bar represented substitutions per nucleotide site. A: 16S SSU rRNA tree B: RPB1 tree.

In conclusion, phylogenetical analysis showed that the current microsporidium from $B$. terrestris was almost identical to $V$. ceranae isolates. So, based on the light microscopy and phylogenetical status the current microsporidium was a new isolate of the V. ceranae and named herein as Vairimorpha ceranae Tr-07 (MW396669). 
In addition, the prevalence of the $V$. ceranae Tr-07 infection from commercial $B$. terrestris members was evaluated in this study. Infection was detected in three of the five provinces where the samples were collected, and the province where the disease was most common was determined as Antalya (15.74\%). When assessed the prevalence according to the months, June was the month that the infection was peaked $(10.16 \%)$ (Table 2). Although greenhouses are areas where controlled air conditions are provided, this situation is eliminated in order to reduce costs in summer months and natural weather conditions are valid in these areas. And in the greenhouses where samples were collected, natural climatic conditions prevailed. There are many studies revealing the variability of $V$. ceranae infection according to weather conditions and months (Gisder et al, 2010; Tosun, 2012; Özgör, Güzerin, \& Keskin, 2015). In 2015, Özgör et al, determined that $V$. ceranae formation in Turkey was directly affected by the temperature and humidity. Similarly, in the current study, the peak point was determined in June which the average data of the temperature and humidity were high relatively. Although the three provinces where $V$. ceranae infection was detected are geographically relatively close to each other, the infection was most frequently detected in Antalya. This situation can be explained due to the variability of the artificial diets of businesses as stated in Gómez-Moracho, Durand, Pasquaretta, Heeb, \& Lihoreau in 2021.

Finally, the current study revealed the first $V$. ceranae infection at the $B$. terrestris in Turkey and its current status.

\section{ACKNOWLEDGEMENTS}

We are thankful to Beekeeper Mehmet TURKUT for making this study possible. All authors designed the project, provided samples and contributed to the preparation of the manuscript.

\section{REFERENCES}

Antúnez, K., Martín-Hernández, R., Prieto, L., Meana, A., Zunino, P., \& Higes, M. (2009). Immune suppression in the honey bee (Apis mellifera) following infection by Nosema ceranae (Microsporidia). Environmental Microbiology, 11(9), 2284-2290. https://doi.org/10.1111/j.1462-2920.2009.01953.x

Argun Karslı, B. \& Gürel, F. (2015). Identification of some important Bumblebee (Bombus terrestris L.) parasites by molecular methods. Uludağ Arıcılık Dergisi, 14(2), 88-98. http://dergipark.gov.tr/uluaricilik/ issue/34048/376896

Baker, M.D., Vossbrinck, C.R., Maddox, J.V., \& Undeen, A.H. (1994). Phylogenetic relationships among Vairimorpha and Nosema species (Microspora) based on ribosomal RNA sequence data. Journal of Invertebrate Pathology, 64(2), 100-106. https://doi.org/10.1006/jipa.1994.1077

Baker, M.D., Vossbrinck, C.R., Didier, E.S., Maddox, J.V., \& Shadduck, J.A. (1995). Small subunit ribosomal DNA phylogeny of various microsporidia with emphasis on AIDS related forms. The Journal of Eukaryotic Microbiology, 42(5), 564-570. https://doi.org/10.1111/j.1550-7408.1995.tb05906.x

Baki, H. \& Bekircan, Ç. (2018). A new microsporidium, Vairimorpha subcoccinellae n. sp. (Microsporidia: Burenellidae), isolated from Subcoccinella vigintiquatuorpunctata L. (Coleoptera: Coccinellidae). Journal of Invertebrate Pathology, 151, 182-190. https://doi.org/10.1016/j.jip.2017.12.004 
Molecular Characterization of the Vairimorpha (Nosema) ceranae

Bekircan, Ç. (2020). Assignment of Vairimorpha leptinotarsae comb. nov. on the basis of molecular characterization of Nosema leptinotarsae Lipa, 1968 (Microsporidia: Nosematidae). Parasitology, 147(9), 1019-1025. https://doi.org/10.1017/S0031182020000669

Cameron, S.A., Lozier, J.D., Strange, J.P., Koch, J.B., Cordes, N., Solter, L.F., \& Griswold, T.L. (2011). Patterns of widespread decline in North American bumble bees. Proceedings of the National Academy of Sciences of the United States of America, 108(2), 662-667. https://doi.org/10.1073/pnas.1014743108

Chen, Y.P., Evans, J.D., Murphy, C., Gutell, R., Zuker, M., Gundensen-Rindal, D., \& Pettis, J.S. (2009). Morphological, molecular, and phylogenetic characterization of Nosema ceranae, a microsporidian parasite isolated from the European honey bee, Apis mellifera. Journal of Eukaryotic Microbiology, 56(2), 142-147. https://doi.org/10.1111/j.1550-7408.2008.00374.x

Cox-Foster, D.L., Conlan, S., Holmes, E.C., Palacios, G., Evans, J.D., Moran, N.A., Quan, P.L., Briese, T., Hornig, M., Geiser, D.M., Martinson, V., VanEngelsdorp, D., Kalkstein, A.L., Drysdale, A., Hui, J., Zhai, J., Cui, L., Hutchison, S.K., Simons, J.F., Lipkin, W.I. (2007). A metagenomic survey of microbes in honey bee colony collapse disorder. Science, 318(5848), 283-287. https://doi.org/10.1126/ science.1146498

Dosselli, R., Grassl, J., Carson, A., Simmons, L.W., \& Baer, B. (2016). Flight behaviour of honey bee (Apis mellifera) workers is altered by initial infections of the fungal parasite Nosema apis. Scientific Reports, 6, 1-11. https://doi.org/10.1038/srep36649

Fitzpatrick, Ú., Murray, T.E., Paxton, R.J., Breen, J., Cotton, D., Santorum, V., \& Brown, M.J.F. (2007). Rarity and decline in bumblebees - A test of causes and correlates in the Irish fauna. Biological Conservation, 136(2), 185-194. https://doi.org/10.1016/j.biocon.2006.11.012

Fries, I., Feng, F., da Silva, A., Slemenda, S.B., \& Pieniazek, N.J. (1996). Nosema ceranae n. sp. (Microspora, Nosematidae), morphological and molecular characterization of a microsporidian parasite of the Asian honey bee Apis cerana (Hymenoptera, Apidae). European Journal of Protistology, 32(3), 356-365. https://doi.org/10.1016/S0932-4739(96)80059-9

Gage, S.L., Kramer, C., Calle, S., Carroll, M., Heien, M., \& DeGrandi-Hoffman, G. (2018). Nosema ceranae parasitism impacts olfactory learning and memory and neurochemistry in honey bees (Apis mellifera). Journal of Experimental Biology, 221(4), 1-11. https://doi.org/10.1242/jeb.161489

Gisder, S., Hedtke, K., Möckel, N., Frielitz, M.C., Linde, A., \& Genersch, E. (2010). Five-year cohort study of Nosema spp. in Germany: Does climate shape virulence and assertiveness of Nosema ceranae? Applied and Environmental Microbiology, 76(9), 3032-3038. https://doi.org/10.1128/AEM.03097-09

Gómez-Moracho, T., Heeb, P., \& Lihoreau, M. (2017). Effects of parasites and pathogens on bee cognition. Ecological Entomology, 42, 51-64. https://doi.org/10.1111/een.12434

Gómez-Moracho, T., Durand, T., Pasquaretta, C., Heeb, P., \& Lihoreau, M. (2021). Artificial diets modulate infection rates by Nosema ceranae in bumblebees. Microorganisms, 9(1), 1-18. https://doi. org/10.3390/microorganisms 9010158

Goulson, D., Lye, G.C., \& Darvill, B. (2008). Decline and conservation of bumble bees. Annual Review of Entomology, 53, 191-208. https://doi.org/10.1146/annurev.ento.53.103106.093454

Graystock, P., Yates, K., Darvill, B., Goulson, D., \& Hughes, W.O.H. (2013). Emerging dangers: Deadly effects of an emergent parasite in a new pollinator host. Journal of Invertebrate Pathology, 114(2), 114-119. https://doi.org/10.1016/j.jip.2013.06.005

Grixti, J.C., Wong, L.T., Cameron, S.A., \& Favret, C. (2009). Decline of bumble bees (Bombus) in the North American Midwest. Biological Conservation, 142(1), 75-84. https://doi.org/10.1016/j. biocon.2008.09.027

Güler, Y., Aytekin, A.M., \& Dikmen F. (2011). Bombini and Halictidae (Hymenoptera: Apoidae) fauna of Afyonkarahisar province of Turkey. Journal of the Entomological Research Society, 13(1), 1-22. https://doi.org/10.51963/jers.v23i2

Hall, T.A. (1999). PdfBioEdit: a user-friendly biological sequence alignment editor and analysis program for Windows 95/98/NT. Nucleic Acids Symposium Series, 41, 95-98. 
Higes, M., García-Palencia, P., Martín-Hernández, R., \& Meana, A. (2007). Experimental infection of Apis mellifera honeybees with Nosema ceranae (Microsporidia). Journal of Invertebrate Pathology, 94(3), 211-217. https://doi.org/10.1016/j.jip.2006.11.001

Holt, H.L., Aronstein, K.A., \& Grozinger, C.M. (2013). Chronic parasitization by Nosema microsporidia causes global expression changes in core nutritional, metabolic and behavioral pathways in honey bee workers (Apis mellifera). BMC Genomics, 14(1). https://doi.org/10.1186/1471-2164-14-799

Huang, W.F., Tsai, S.J., Lo, C.F., Soichi, Y., \& Wang, C.H. (2004). The novel organization and complete sequence of the ribosomal RNA gene of Nosema bombycis. Fungal Genetics and Biology, 41(5), 473-481. https://doi.org/10.1016/j.fgb.2003.12.005

Kudo, R. (1924). A biologic and taxonomic study of the Microsporidia. Illinois Biological Monographs, 9 , 1-268.

Li, J., Chen, W., Wu, J., Peng, W., An, J., Schmid-Hempel, P., \& Schmid-Hempel, R. (2012). Diversity of nosema associated with bumblebees (Bombus spp.) from China. International Journal for Parasitology, 42(1), 49-61. https://doi.org/10.1016/j.ijpara.2011.10.005

Li, W., Chen, Y., \& Cook, S.C. (2018). Chronic Nosema ceranae infection inflicts comprehensive and persistent immunosuppression and accelerated lipid loss in host Apis mellifera honey bees. International Journal for Parasitology, 48(6), 433-444. https://doi.org/10.1016/j.ijpara.2017.11.004

Martín-Hernández, R., Meana, A., Prieto, L., Salvador, A.M., Garrido-Bailón, E., \& Higes, M. (2007). Outcome of colonization of Apis mellifera by Nosema ceranae. Applied and Environmental Microbiology, 73(20), 6331-6338. https://doi.org/10.1128/AEM.00270-07

Martín-Hernández, R., Higes, M., Sagastume, S., Juarranz, Á., Dias-Almeida, J., Budge, G.E., Meana, A., \& Boonham, N. (2017). Microsporidia infection impacts the host cell's cycle and reduces host cell apoptosis. PLoS ONE, 12(2), 1-17. https://doi.org/10.1371/journal.pone.0170183

Martín-Hernández, R., Bartolomé, C., Chejanovsky, N., Le Conte, Y., Dalmon, A., Dussaubat, C., García-Palencia, P., Meana, A., Pinto, M.A., Soroker, V., \& Higes, M. (2018). Nosema ceranae in Apis mellifera: a 12 years postdetection perspective. Environmental Microbiology, 20(4), 1302-1329. https://doi.org/10.1111/1462-2920.14103

Mauss, V. (1994). Bestimmungsschlüssel für Hummeln. Deutscher Jugendbund für Naturbeobachtungen (DJN), $55 \mathrm{~s}$.

Nägeli, K.W. (1857). Überdie neue Krankheit der Seidenraupe und verwandte Organismen. Botanische Zeitung, 15, 60-761.

Özgör, E., Güzerin, E., \& Keskin, N. (2015). Determination and comparison of Nosema apis and Nosema ceranae in terms of geographic and climatic factors. Hacettepe Journal of Biology and Chemistry, 43(1), 9-15. https://doi.org/10.15671/HJBC.20154311200

Perry, C.J., Søvik, E., Myerscough, M.R., \& Barron, A.B. (2016). Rapid behavioral maturation accelerates failure of stressed honey bee colonies. Proceedings of the National Academy of Sciences of the United States of America, 113(30), E4431. https://doi.org/10.1073/pnas.1610243113

Piiroinen, S. \& Goulson, D. (2016). Chronic neonicotinoid pesticide exposure and parasite stress differentially affects learning in honeybees and bumblebees. Proceedings of the Royal Society B: Biological Sciences, 283(1828). https://doi.org/10.1098/rspb.2016.0246

Pilley, B.M. (1976). A new genus, Vairimorpha (Protozoa: Microsporida), for Nosema necatrix Kramer 1965: Pathogenicity and life cycle in Spodoptera exempta (Lepidoptera: Noctuidae). Journal of Invertebrate Pathology, 28(2), 177-183. https://doi.org/10.1016/0022-2011(76)90119-1

Plischuk, S., Martín-Hernández, R., Prieto, L., Lucía, M., Botías, C., Meana, A., Abrahamovich, A.H., Lange, C., \& Higes, M. (2009). South American native bumblebees (Hymenoptera: Apidae) infected by Nosema ceranae (Microsporidia), an emerging pathogen of honeybees (Apis mellifera). Environmental Microbiology Reports, 1(2), 131-135. https://doi.org/10.1111/j.1758-2229.2009.00018.x

Plischuk, S. \& Lange, C.E. (2016). Bombus brasiliensis Lepeletier (Hymenoptera, Apidae) infected with Nosema ceranae (Microsporidia). Revista Brasileira de Entomologia, 60(4), 347-351. https://doi. org/10.1016/j.rbe.2016.06.003 
Molecular Characterization of the Vairimorpha (Nosema) ceranae

Sinpoo, C., Disayathanoowat, T., Williams, P.H., \& Chantawannakul, P. (2019). Prevalence of infection by the microsporidian Nosema spp. in native bumblebees (Bombus spp.) in northern Thailand. PLOS ONE, 14(3), e0213171. https://doi.org/10.1371/journal.pone.0213171

Sprague, V., Becnel, J.J., \& Hazard, E.I. (1992). Taxonomy of phylum microspora. Critical Reviews in Microbiology, 18(5-6), 285-395. https://doi.org/10.3109/10408419209113519

Tokarev, Y.S., Huang, W.F., Solter, L.F., Malysh, J.M., Becnel, J.J., \& Vossbrinck, C.R. (2020). A formal redefinition of the genera Nosema and Vairimorpha (Microsporidia: Nosematidae) and reassignment of species based on molecular phylogenetics. Journal of Invertebrate Pathology, 169 (October 2019), 107279. https://doi.org/10.1016/j.jip.2019.107279

Tosun, O. (2012). Bal Arılarında (Apis mellifera L., 1758) Nosemosis (Nosematosis) Hastalığının Doğu Karadeniz Bölgesinde Bulunan Arı Kolonilerindeki Varlığı, Dağılımı ve Hastalık Etkenlerinin Karakterizasyonu. [Doctora tezi, Karadeniz Teknik Üniversitesi]. Fen Bilimleri Enstitüsü, $112 \mathrm{~s}$.

Tosun, O. (2020). A new isolate of Nosema fumiferanae (Microsporidia: Nosematidae) from the date moth Apomyelois (Ectomyelois) ceratoniae, Zeller, 1839 (Lepidoptera: Pyralidae). Parasitology, 147(13), 1461-1468. https://doi.org/10.1017/S0031182020001481

Velthius, H.W. \& Doorn, A. Van. (2006). A century of advances in bumblebee domestication and the economic and environmental aspects of its commercialization for pollination. Apidologie, 37, 421-451.

Weiser, J. (1977). Contribution to the classification of Microsporidia. Vestnik Ceskoslovenske Spolecnosti Zoologicke, 41, 308-320.

Williams, P.H. \& Osborne, J.L. (2009). Bumblebee vulnerability and conservation world-wide. Apidologie, 40(3), 367-387. https://doi.org/10.1051/apido/2009025

Wolf, S., McMahon, D.P., Lim, K.S., Pull, C.D., Clark, S.J., Paxton, R.J., \& Osborne, J.L. (2014). So near and yet so far: Harmonic radar reveals reduced homing ability of nosema infected honeybees. PLoS ONE, 9(8). https://doi.org/10.1371/journal.pone.0103989

Yıldırım, H. (2021). The first record of Vairimorpha hostounsky sp. nov. Infection in the blue shieldbug, Zicrona caerulea Linnaeus, 1758 (Hemiptera: Pentatomidae). Microbial Pathogenesis, 155, 104883. https://doi.org/10.1016/j.micpath.2021.104883

Yıldırım, H. \& Bekircan, Ç. (2020). Ultrastructural and molecular characterization of Nosema alticae sp. nov. (Microsporidia: Nosematidae), pathogen of the flea beetle, Altica hampei Allard, 1867 (Coleoptera: Chrysomelidae). Journal of Invertebrate Pathology, 170(November 2019). https://doi. org/10.1016/j.jip.2019.107302 